\title{
PENDUGAAN PARAMETER GENETIK DAN KOMPONEN RAGAM SIFAT PERTUMBUHAN PADA BANGSA BABI LANDRACE
}

\section{ESTIMATION OF GENETIC PARAMETERS AND VARIAN COMPONENT OF GROWING UP CHARACTER FOR LANDRACE SWINE}

\author{
Vierman ${ }^{1}$, Marida S. Nababan ${ }^{2}$ Armyn Hakim Daulay ${ }^{3}$ dan Hamdan ${ }^{3}$ \\ 1. Kepala Balai Pembibitan Ternak unggul Kerbau dan Babi Siborong-Borong, Sumut \\ 2. Mahasiswa Program Studi Peternakan Fakultas Pertanian Universitas Sumatera Utara \\ 3. Staf Pengajar Program Studi Peternakan Fakultas Pertanian Universitas Sumatera Utara
}

\begin{abstract}
The genetic information of Landrace can determine the breeding strategy in the future. This study aimed to find out the heritability value, genetic correlation, and breeding value of Landrace swine. This research was conducted at Balai Penelitian Ternak Unggul dan Hijauan Pakan Ternak Siborongborong, Tapanuli Utara on June 2015. The research used nested unbalanced design. The research used data record of production from 465 Landrace Swine with 245 male swine and 220 female swine. The result showed that the heritability value of birth weight and weaning weight were 0.14 and 0.36, respectively. Genetic correlation value (birth weight - weaning weight) (litter size - birth weight) (litter size - weaning birth) were $0.24 \%$; $-0.06 \%$ and $-0.14 \%$, respectively. The conclusion of this research is the coefficient variance of growth trait on Landrace swine is high however, have low correlation. Criteria selection of growth trait based on birth weight and weaning weight.
\end{abstract}

Keywords: Landrace swine, heritability, genetic correlations, breeding value.

\begin{abstract}
ABSTRAK
Informasi genetik babi Landrace menentukan strategi pemuliaan di masa mendatang. Penelitian ini bertujuan mengetahui nilai heritabilitas, korelasi genetik, dan nilai pemuliaan babi Landrace. Penelitian dilakukan di Balai Pembibitan Ternak Unggul dan Hijauan Pakan Ternak Desa Siaro Kecamatan Siborongborong Kabupaten Tapanuli Utara pada bulan Juni 2015. Rancangan yang digunakan adalah pola tersarang data tidak seimbang. Materi penelitian merupakan data produksi dari 465 ekor Babi Landrace dengan jantan sebanyak 245 ekor dan betina sebanyak 220 ekor. Hasil penelitian menunjukkan nilai heritabilitas bobot lahir dan bobot sapih berturut-turut adalah 0.14 dan 0.36. Nilai korelasi genetik (bobot lahir-bobot sapih) (jumlah anak sekelahiran-bobot lahir) (jumlah anak sekelahiran-bobot sapih) dengan nilai masing-masing adalah: $0.24 \%$; $-0.06 \%$ dan $-0.14 \%$. Kesimpulan penelitian adalah nilai koefisien keragaman sifat pertumbuhan pada babi Landrace memiliki keragaman yang tinggi namun korelasi genetiknya rendah. Kriteria terhadap seleksi sifat pertumbuhan pada babi Landrace didasarkan pada bobot lahir dan bobot sapih.
\end{abstract}

Kata kunci : Babi Landrace, heritabilitas, korelasi genetik, nilai pemuliaan. 


\section{PENDAHULUAN}

Babi adalah ternak monogastrik dengan interval generasi yang lebih singkat dari domba, sapi, kerbau dan kuda serta pertumbuhan yang cepat. Ternak babi merupakan hewan polytocous (melahirkan anak lebih dari satu), serta jarak antara satu kelahiran dengan kelahiran berikutnya pendek.

Dilihat dari keberadaannya, produksi ternak babi yang dipelihara oleh masyarakat belum memberikan hasil yang optimal. Perkembangan dunia usaha peternakan tidak terlepas dari faktor bibit, pakan dan manajemen. Faktor-faktor tersebut harus diperhatikan dan dilaksanakan dengan baik untuk mendapatkan penampilan ternak yang diinginkan sehingga mendatangkan keuntungan yang diharapkan. Peningkatan produktivitas dari segi pemuliaan didukung oleh perbaikan mutu genetik melalui seleksi pada pejantan karena sekitar 50\% sifat diwariskan pejantan kepada keturunannya. Hal ini lah yang mendorong para peneliti untuk memperbaiki produksi ternak khususnya ternak babi melalui penelitian pemuliaan ternak.

Keragaman fenotipik sifat menunjukkan perbedaan yang terukur antara individu yang satu dengan individu yang lain dalam suatu populasi untuk sifat tertentu. Keragaman fenotipik sifat menjadi materi dasar yang harus diperhatikan oleh pemulia karena tanpa keragaman sifat maka sifat tersebut tidak dapat diseleksi. Faktor-faktor yang menyebabkan keragaman fenotipik adalah faktor genetik, faktor lingkungan, dan interaksi keduanya (Kurnianto, 2009).

Jumlah anak perkelahiran (littersize) dan kemampuan induk dalam mengasuh anak merupakan rangkaian yang tak terpisah-pisahkan dalam menghasilkan sejumlah anak babi hidup sampai disapih. Anak babi dengan bobot lahir yang tinggi mempunyai pertambahan bobot badan harian (daily again) dan bobot sapih yang lebih baik dari pada anak-anak babi yang bobot lahirnya rendah. Babi Landrace menjadi pilihan para peternak karena pertumbuhannya cepat, konversi makanan sangat bagus dan temperamennya jinak.

Berdasarkan pemaparan di atas maka perlu diadakan seleksi di dalam pemilihan bibit unggul. Melalui pendugaan nilai parameter genetik dan ragam sifat pertumbuhan maka setiap ternak akan diketahui nilai pemuliaan dan peringkat mutu genetiknya dalam suatu populasi tersebut. Individu dengan 
rangking tertinggi memiliki potensi genetik untuk ternak seleksi guna memperbaiki mutu genetik dalam suatu populasi ternak diwaktu mendatang. Dengan demikian perkawinan ternak bukan terjadi secara kebetulan dan liar melainkan teratur dan terarah.

\section{BAHAN DAN METODE PENELITIAN}

\section{Tempat dan Waktu Penelitian}

Penelitian dilaksanakan di Balai Penelitian Ternak Unggul dan Hijauan Pakan Ternak Sinur, Desa Siaro, Kecamatan Siborongborong, Kabupaten Tapanuli Utara, sekitar 255-260 km dari Kota Medan dengan ketinggian lokasi sekitar $1250 \mathrm{~m}$ di atas permukaan laut, dengan suhu berkisar $20-25^{\circ} \mathrm{C}$. Penelitian akan dilakukan pada bulan Juni 2015.

\section{Bahan dan Alat Penelitian}

\section{Bahan}

Bahan yang digunakan dalam penelitian ini adalah data recording bangsa babi galur murni Australia (Landrace) yaitu dengan menggunakan data time series selama 1 generasi berupa (nomor dan bangsa tetua, tanggal kawin, tanggal lahir, nomor anak, jenis kelamin, bobot lahir, bobot sapih, jumlah anak sekelahiran dan jumlah anak yang disapih) diperoleh dari catatan atau recording bangsa babi galur murni Australia (Landrace) di BPTU - HPT Siborongborong. Jumlah data recording ternak babi galur murni Australia (Landrace) di BPTU-HPT Siborongborong yang digunakan pada penelitian berkisar 245 ekor betina dan 220 ekor jantan.

\section{Alat}

Pada penelitian ini digunakan buku dan alat tulis untuk mencatat data recording ternak babi galur murni Australia bangsa Landrace.

\section{Metode Penelitian}

Metode yang digunakan adalah metode pengambilan data recording berupa data time series dalam 1 generasi. Data recording ini diperoleh dari instansi terkait dengan menggunakan data time series yaitu nomor dan bangsa tetua, tanggal kawin, tanggal lahir, nomor anak, jenis kelamin, bobot lahir, bobot 
sapih, jumlah anak sekelahiran dan jumlah anak yang disapih pada bangsa babi Landrace dalam 1 generasi.

\section{Parameter Penelitian}

\section{Komponen Ragam}

Sesuai pernyataan Kurnianto (2010) komponen ragam terdiri dari ragam, koefisien keragaman, dan peragam berdasarkan kuantitatif sebagai berikut :
a. Bobot lahir
b. Bobot sapih
c. Jumlah anak sekelahiran

Rumus bobot badan terkoreksi adalah sebagai berikut :

$$
\begin{aligned}
& \mathrm{BL}_{\mathrm{T}}=\mathrm{BL} x \mathrm{FKJK}_{\mathrm{BL}} \\
& \mathrm{BS}_{\mathrm{T}}=\mathrm{BS} x \mathrm{FKJK}_{\mathrm{BS}}
\end{aligned}
$$

Keterangan :

$\mathrm{BL}_{\mathrm{T}} \quad=$ Bobot lahir terkoreksi $(\mathrm{kg})$

$\mathrm{BS}_{\mathrm{T}}=$ Bobot sapih terkoreksi $(\mathrm{kg})$

\subsection{Ragam $\left(\sigma^{2}\right)$}

Ragam $\left(\sigma^{2}\right)$ merupakan rata-rata kuadrat simpangan ukuran masingmasing individu paling berguna untuk mempelajari keragaman populasi (Kurnianto, 2010).

$$
\sigma^{2}=\frac{\sum\left(X_{i}-\mu\right)^{2}}{N}
$$

Keterangan :

$\sigma^{2}=$ ragam untuk populasi

$\mathrm{N}$ = banyaknya data populasi

$\mu=$ rata-rata populasi

\subsection{Koefisien Keragaman (KK)}

Pada umumnya, benda besar beragam dan benda kecil beragam kecil. Untuk membuat perbandingan, akan mudah bila simpangan baku dinyatakan sebagai persentase dari rata-rata. Simpangan baku yang dinyatakan sebagai persentase dari rata-rata disebut koefisien keragaman (Kurnianto, 2010).

$$
\mathrm{KK}=\frac{\sigma}{\mu}(100 \%)
$$


Keterangan :

$\sigma=$ standar deviasi untuk populasi

$\mu=$ rata-rata populasi

\subsection{Peragam}

Peragam adalah salah satu perhitungan yang harus dilakukan untuk mengetahui bentuk hubungan dan keeratan hubungan antara 2 atau lebih parameter kuantitatif (Kurnianto, 2010).

$$
S_{\mathrm{xy}}=\frac{\sum X Y}{n-1}=\frac{\sum X Y-\left\{\frac{\left[\left(\sum X\right)(\Sigma Y)\right]}{n}\right.}{n-1}
$$

\section{Parameter Genetik}

\subsection{Estimasi Nilai Heritabilitas $\left(\mathbf{h}^{2}\right)$}

Dengan metode rancangan tersarang (nested design) un-balanced, nilai pendugaan heritabilitas dari pejantan $\left(h^{2} S\right)$ dan betina $\left(h^{2} S\right)$ akan dihitung menggunakan rumus menurut Kurnianto (2010) sebagai berikut :

$$
\begin{aligned}
h^{2} S & =\frac{4 \sigma^{2} s}{\left(\sigma^{2} s+\sigma^{2} d+\sigma^{2} w\right)} \\
h^{2} D & =\frac{4 \sigma^{2} d}{\left(\sigma^{2} s+\sigma^{2} d+\sigma^{2} w\right)}
\end{aligned}
$$

Untuk model Unbalanced design, perhitungan koefisien-koefisien $\left(\mathrm{k}_{1}, \mathrm{k}_{2}\right.$, dan $\mathrm{k}_{3}$ ) yang menunjukkan anak per induk dan per pejantan pada kondisi tidak sama dilakukan dengan rumus-rumus sebagai berikut:

$$
\begin{aligned}
& \mathrm{K}_{1}=\left(\mathrm{n} . .-\sum_{i} \frac{\sum n^{2} i j}{n i .}\right) / \mathrm{DB}_{\mathrm{D}} \\
& \mathrm{K}_{2}=\left(\sum_{i} \frac{\sum_{j} n^{2}{ }_{i j}}{n i .}-\frac{\sum_{i} \sum_{j} n^{2} i j}{n . .}\right) / \mathrm{DB}_{\mathrm{S}} \\
& \mathrm{K}_{3}=\left(\mathrm{n} . .-\frac{\sum_{i} n i^{2}}{n . .}\right) / \mathrm{DB}_{\mathrm{S}}
\end{aligned}
$$




\subsection{Estimasi Korelasi Genetik (rG)}

Estimasi korelasi genetik akan dilakukan dengan metode pola tersarang (Nested design) dengan analisa peragam (Covarians) menurut Kurnianto (2010) sebagai berikut :

Korelasi genetik $\left(r_{\mathrm{g}}\right)=\frac{4 \operatorname{Covs}}{\sqrt{4 \sigma^{2} \mathrm{~s}(\mathrm{X}) \cdot 4 \sigma^{2} \mathrm{~s}(\mathrm{Y})}}$

\subsection{Estimasi Nilai Pemuliaan (Estimated Breeding Value)}

Menurut Kurnianto (2010), nilai pemuliaan dapat ditaksir dengan menggunakan satu catatan produksi dari 1 individu, yaitu :

$$
\mathrm{EBV}=\mathrm{h}^{2}(P-\bar{P})
$$

Keterangan :

$\mathrm{EBV}=$ Estimated Breeding Value

$\mathrm{h}^{2} \quad=$ Nilai heritabilitas sebagai pembobot

$\mathrm{P} \quad=$ Produksi dari catatan tunggal ternak yang sedang dihitung NP nya

$\overline{\mathrm{P}} \quad=$ Rata-rata produksi dari ternak pembanding (ternak-ternak lain yang berproduksi pada tempat dan waktu yang sama).

\section{Analisis Data}

Analisis terhadap sifat kuantitatif (bobot badan nyata dan terkoreksi), heritabilitas dan nilai pemuliaan dilakukan dengan program Microsoft Excel. Sedangkan nilai korelasi genetik dilakukan dengan bantuan program SPSS.

\section{HASIL DAN PEMBAHASAN}

Sesuai analisis statistik hasil penelitian dapat dilihat pada tabel rekapitulasi hasil penelitian sebagai berikut: 
Tabel 1. Rekapitulasi hasil penelitian pendugaan parameter genetik dan komponen ragam sifat pertumbuhan babi Landrace.

\begin{tabular}{|c|c|c|c|c|c|c|}
\hline \multirow{3}{*}{\multicolumn{2}{|c|}{ Sifat Pertumbuhan }} & \multicolumn{5}{|c|}{ Parameter penelitian } \\
\hline & & \multicolumn{2}{|c|}{ Komponen Ragam } & & \multicolumn{2}{|c|}{ Parameter Genetik } \\
\hline & & \multirow{2}{*}{$\begin{array}{c}\text { Ragam } \\
0.10\end{array}$} & $\begin{array}{l}\text { Koefisien } \\
\text { keragaman } \\
(\%)\end{array}$ & Peragam & Heritabilitas & $\begin{array}{l}\text { Korelasi } \\
\text { genetik }\end{array}$ \\
\hline & $\begin{array}{l}\text { a.Bobot } \\
\text { lahir }\end{array}$ & & 19.98 & & & \\
\hline $\begin{array}{l}\text { Bobot } \\
\text { lahir }\end{array}$ & $\begin{array}{l}\text { b.Bobot } \\
\text { lahir } \\
\text { terkoreksi }\end{array}$ & 0.11 & 19.88 & & & \\
\hline & a.Bobot & 6.61 & 22.70 & & 0.36 & \\
\hline $\begin{array}{l}\text { Bobot } \\
\text { sapih }\end{array}$ & $\begin{array}{l}\text { sapih } \\
\text { b.Bobot } \\
\text { sapih } \\
\text { terkoreksi }\end{array}$ & 6.67 & 22.65 & & & \\
\hline $\begin{array}{l}\text { Jumlal } \\
\text { sekela }\end{array}$ & $\begin{array}{l}\text { rnak } \\
\text { ran }\end{array}$ & 5.13 & 27.89 & & & \\
\hline $\begin{array}{l}\text { Bobot } \\
\text { sapih }\end{array}$ & hir-bobot & & & 0.21 & & 0.24 \\
\hline $\begin{array}{l}\text { Jumlal } \\
\text { sekela } \\
\text { lahir }\end{array}$ & ran-bobot & & & -0.05 & & -0.06 \\
\hline $\begin{array}{l}\text { Jumlal } \\
\text { sekela } \\
\text { sapih }\end{array}$ & $\begin{array}{l}\text { anak } \\
\text { ran-bobot }\end{array}$ & & & -0.82 & & -0.14 \\
\hline
\end{tabular}

\section{Komponen Ragam}

Koreksi terhadap jenis kelamin menunjukkan bahwa bobot badan terkoreksi lebih besar yaitu dengan nilai 1,64 dibandingkan bobot badan nyata dengan nilai 1,61. Demikian juga dengan nilai ragam (Tabel 1) bobot badan terkoreksi lebih tinggi dengan nilai 0,11 dibandingkan nilai ragam bobot badan nyata dengan nilai 0,10 . Hal ini menunjukkan keragaman data setelah dikoreksi lebih rendah dibandingkan tidak dikoreksi. Keragaman data pada bobot badan dapat terjadi disebabkan beberapa faktor seperti faktor umur induk, genetik, manajemen, dan fertilitas pejantan sehingga perlu diadakan koreksi terhadap data bobot badan. Menurut Davendra and Mcleroy (1982) tujuan koreksi data adalah untuk mengurangi pengaruh keragaman data yang disebabkan oleh faktor lingkungan. Variasi yang tinggi akan berpengaruh terhadap nilai parameter 
genetik. Sehingga proses seleksi bersifat fair yang bebas dari pengaruh (Kurnianto, 2010).

Nilai keragaman dari sifat bobot lahir dan bobot sapih memiliki keragaman yang besar yaitu di atas $15 \%$. Hal ini sesuai dengan pernyataan Kurnianto (2009) yang menyatakan bahwa kategori keragaman ialah: <5\% keragaman kecil, $6 \%-14 \%$ keragaman sedang, $\geq 15 \%$ keragaman besar. Keragaman pada sifat terkoreksi pada bobot sapih lebih besar dibandingkan koreksi bobot lahir disebabkan karena bobot sapih masing-masing individu telah menunjukkan potensi genetiknya yang sangat variatif terhadap lingkungan.

Peragam dihitung untuk mengetahui tingkat keeratan hubungan antara dua sifat pertumbuhan tertentu. Kurnianto (2009) menyatakan bahwa untuk mengetahui bentuk hubungan dan keeratan hubungan antara dua parameter atau variabel, maka salah satu perhitungan yang harus dilakukan adalah peragam. Pada Tabel 1 nilai peragam antara sifat jumlah anak sekelahiran dengan bobot lahir yaitu -0.05 . Kedua sifat tersebut memiliki nilai peragam yang negatif dan kategori sangat rendah, yaitu apabila terjadi peningkatan pada sifat yang satu akan menurunkan sifat yang satunya. Artinya dengan kenaikan jumlah anak sekelahiran maka akan menurunkan bobot lahir.

Nilai peragam pada sifat pertumbuhan antara jumlah anak sekelahiran dengan bobot sapih yaitu $\quad-0.82$. Kedua sifat tersebut memiliki nilai peragam yang negatif dengan kategori tinggi, sehingga sifat jumlah anak sekelahiran dengan sifat bobot sapih memiliki hubungan yang saling berlawanan yaitu apabila dengan kenaikan pada satu sifat akan menurunkan sifat yang lain. Artinya dengan kenaikan jumlah anak sekelahiran akan menurunkan bobot sapih. Hal ini sesuai dengan pernyataan Munir (2013), yang menyatakan bahwa tanda kovarians (+ atau -) menunjukkan hubungan antara peubah acak positif/negatif. Jika bergerak ke arah berlawanan $\quad(\mathrm{x}$ membesar dan y mengecil), maka hasil kali $(\mathrm{x}-\mu \mathrm{x})(\mathrm{y}-$ $\mu y)$ cenderung akan bernilai negatif.

Nilai peragam antara sifat bobot lahir dan bobot sapih termasuk di dalam kategori rendah sehingga sifat bobot lahir dan bobot sapih memiliki hubungan yang rendah. Kedua sifat tersebut memiliki nilai yang rendah dan positif, yaitu apabila terjadi penurunan pada sifat bobot lahir maka akan menurunkan sifat 
bobot sapih. Hal ini sesuai dengan pernyataan Munir (2013), yang menyatakan bahwa peragam antara dua peubah menunjukkan sifat asosiasi (hubungan) antara keduanya. Jika peubah tersebut bergerak searah (x membesar dan y membesar) maka hasil kali $(\mathrm{x}-\mu \mathrm{x})(\mathrm{y}-\mu \mathrm{y})$ cenderung bernilai positif.

\section{Bobot Lahir}

Rata-rata bobot lahir pada anak jantan $(1.64 \pm 0.31)$ dan betina $(1.57 \pm$ 0.32). Hal ini sesuai dengan pernyataan Sihombing (1997) yang meyatakan bahwa rataan bobot lahir anak babi Landrace bervariasi antara 1,09-1,77 kg.

Berdasarkan jenis kelamin bobot lahir anak jantan lebih besar dibandingkan betina. Hal ini berkaitan dengan kemampuan sifat fetus jantan lebih baik dalam mengekspresikan gen dan menyerap nutrisi dari induk dibandingkan betina. Hal ini sesuai dengan pernyataan Sihombing (1997), yang menyatakan bahwa bobot lahir anak sangat bervariasi dan dipengaruhi beberapa faktor seperti genetik, pakan, jenis kelamin (Widodo dan Hakim, 1981). Bobot lahir juga dipengaruhi oleh faktor keindukan (maternal effect), dimana hal ini sesuai dengan pernyataan Toelihere (1981) yang menyatakan bahwa selama pertumbuhan prenatal (di dalam uterus), plasenta jantan lebih besar jika dibandingkan dengan betina. Dengan demikian kesempatan fetus jantan untuk memperoleh zat makanan cukup banyak jika dibandingkan dengan yang betina.

\section{Bobot Sapih}

Hasil analisis bobot sapih babi Landrace berdasarkan jenis kelamin pada jantan yaitu $(11.39 \pm 2.57)$ dan pada betina $(11.29 \pm 2.57)$, lebih rendah dibandingkan dengan bobot sapih pada babi Landrace secara umum yang direkomendasikan oleh NRC (1998) yaitu sekitar 13-18 kg. Bobot sapih sangat ditentukan antara lain oleh jenis kelamin, bobot badan induk, keadaan saat ternak lahir dan kemampuan induk menyusui anaknya, kuantitas dan kualitas ransum serta suhu lingkungan (Sihombing, 1997) dan hal ini didukung oleh pernyataan Bourdon (1997), yang menyatakan bahwa bobot sapih dipengaruhi komponen genetik induk (maternal genetic effect) yaitu pengaruh gen yang mempengaruhi kondisi lingkungan pada induk dan akhirnya mempengaruhi performans individu.

Variasi bobot badan dari berbagai penelitian dapat disebabkan oleh faktor seperti perbedaan jumlah ternak penelitian, metode yang digunakan dan 
perbedaan waktu penelitian. Hal ini sesuai dengan pernyataan Prihandini et al., (2011) yang menyatakan faktor lingkungan (non-genetik) tidak seluruhnya dapat diseragamkan karena pola pemeliharaan ternak setiap tahunnya tidak sama.

\section{Jumlah Anak Sekelahiran}

Berdasarkan hasil penelitian menunjukkan bahwa rata-rata jumlah anak sekelahiran pada ternak babi Landrace sebesar 8.12 ekor. Jumlah anak sekelahiran pada kelahiran pertama bervariasi antara 6.71-9.45 ekor bagi bangsa murni Australia (Landrace) dan angka ini akan naik sampai induk berumur 3 tahun atau kelahiran ke 5 yang bervariasi antara 8.32-12.43 ekor (Brahmana et al., 1976). Babi dara yang baru dikawinkan akan menghasilkan jumlah anak sekelahiran yang lebih sedikit daripada babi induk (Sihombing, 1997).

Jumlah anak sekelahiran pada babi Landrace memiliki keragaman yang besar yaitu $27.89 \%$ (Tabel 1). Tingginya keragaman dari sifat pertumbuhan babi Landrace menunjukkan bahwa dapat dilakukan perbaikan genetiknya. Hal ini sesuai dengan pernyataan Pane (1993), yang menyatakan bahwa makin besar variasinya makin besar pula kemungkinan dapat dilaksanakan perbaikan mutu secara keseluruhannya. Variasi dapat terjadi pada sifat yang terlihat (fenotip) dan yang tidak terlihat (genotip).

\section{Estimasi Nilai Heritabilitas}

Hasil analisis statistik (Tabel 1) nilai heritabilitas sifat bobot lahir adalah 0.14 dan nilai heritabilitas pada sifat bobot sapih adalah 0.36 . Nilai pewarisan pada sifat bobot lahir yang diperoleh dari hasil penelitian tergolong sedang dan nilai pewarisan pada sifat bobot sapih tergolong tinggi. Hal ini sesuai dengan pernyataan Hardjosubroto (1994), yang menyatakan bahwa pada umumnya $\mathrm{h}^{2}$ dikatakan rendah bila nilainya berkisar antara 0 sampai 0.1 , sedang bila nilainya 0.1 sampai 0.3 dan tinggi bila melebihi 0.3. Kurnianto (2009), menyatakan bahwa faktor-faktor yang membedakan nilai heritabilitas suatu sifat diantaranya pada periode waktu yang berbeda, sifat suatu bangsa, dan metode yang digunakan dalam pendugaan serta jumlah dan asal data yang berbeda.

Bila dibandingkan dengan nilai heritabilitas bobot lahir, maka pengaruh ragam lingkungan pada heritabilitas bobot sapih ternak babi Landrace yang diteliti lebih rendah. Pengaruh gen aditif lebih besar pada bobot sapih 
menyebabkan nilai heritabilitas yang dihasilkan lebih tinggi dibandingkan heritabilitas bobot lahirnya. Tingginya nilai pewarisan pada sifat bobot sapih dibandingkan pada sifat bobot lahir maka harapan untuk mendapatkan kemajuan atau perbaikan mutu genetik relatif lebih cepat pada sifat bobot sapih, karena dengan heritabilitas tinggi maka waktu yang dibutuhkan untuk mencapai kemajuan genetik relatif cepat. Menurut Dalton (1984) nilai heritabilitas dikatakan tinggi jika lebih dari 0,3 .

Nilai heritabilitas dengan kategori sedang sampai tinggi menggambarkan bahwa faktor genetik sangat berperan dalam menentukan keragaman fenotipik ternak, sehingga dapat secara maksimal dimanfaatkan dalam peningkatan kemajuan genetik melalui program seleksi. Hardjosubroto (1994) menambahkan bahwa suatu sifat apabila memiliki nilai heritabilitas yang tinggi apabila digunakan untuk seleksi maka akan menunjukkan respon seleksi yang tinggi. Karena nilai heritabilitas sifat bobot sapih pada penelitian lebih tinggi dibandingkan dengan sifat bobot lahir, maka seleksi akan lebih berhasil dan efisien apabila dilakukan pada saat ternak akan disapih.

\section{Korelasi Genetik}

Hasil analisis statistik (Tabel 1) menunjukkan nilai korelasi antara bobot lahir-bobot sapih yaitu sebesar 0.24, lebih tinggi dibandingkan korelasi jumlah anak sekelahiran-bobot lahir dan jumlah anak sekelahiran-bobot sapih masingmasing adalah -0.06 dan -0.14 . Nilai korelasi tersebut tergolong rendah sesuai dengan pernyataan Warwick et al., (1984) yang menyatakan bahwa nilai korelasi tinggi berkisar antara 0.5-1.0; sedang berkisar antara 0.25-0.5 dan rendah <0.25. Nilai korelasi hanya berlaku pada populasi dimana nilai tersebut diduga dan pada kurun waktu tertentu.

Nilai korelasi antara bobot lahir dengan bobot sapih sebesar 0.24 menunjukkan bahwa sifat bobot lahir berkorelasi genetik positif berderajat sedang dengan sifat bobot sapih. Jadi seleksi dengan sifat bobot sapih diharapkan dapat meningkatkan kenaikan bobot lahir generasi selanjutnya sebagai tanggapan seleksi. Hal ini sesuai dengan pernyataan Warwick et al (1995), yang menyatakan bahwa korelasi dapat positif apabila satu sifat meningkat, maka sifat lain juga meningkat. Noor (1996) menambahkan bahwa korelasi genetik yang positif ada 
jika seleksi untuk suatu sifat tidak saja berakibat diperbaikinya sifat tersebut, tetapi juga sifat keduanya yang berkorelasi. Makin tinggi nilai korelasinya maka makin erat hubungan antara kedua sifat tersebut.

Nilai korelasi jumlah anak sekelahiran dengan bobot lahir dan jumlah anak sekelahiran dengan bobot sapih berturut-turut adalah -0.06 dan -0.14. Nilai tersebut menunjukkan bahwa sifat jumlah anak sekelahiran berkorelasi genetik negatif berderajat rendah dengan sifat bobot lahir dan bobot sapih. Hal ini menunjukkan jumlah anak sekelahiran yang tinggi dapat menurunkan bobot lahir dan bobot sapih dari babi Landrace. Hal ini sesuai dengan pernyataan Noor (1996), yang menyatakan bahwa jika dua sifat berkorelasi negatif maka kemajuan seleksi pada sifat akan mengakibatkan menurunnya kemajuan genetik untuk sifat keduanya. Sesuai dengan pernyataan Lasley (1978), nilai korelasi rendah menunjukkan bahwa gen yang mempengaruhi kedua sifat tersebut masih sangat sedikit sekali dan tidak dapat dipakai sebagai tolak ukur program seleksi (Hakim, 1999). Rendahnya hubungan tersebut dikarenakan pada bobot lahir masih dipengaruhi faktor maternal effect (induk) (Bourdon, 1997) sedangkan pada bobot sapih dipengaruhi potensi pertumbuhan masing-masing individu (Cole, 1982).

\section{Nilai Pemuliaan (Estimated Breeding Value)}

Sesuai hasil analisis statistik menunjukkan nilai pemuliaan bobot lahir dan bobot sapih dari 245 ekor anak jantan dan 220 ekor anak betina babi Landrace yang telah dievaluasi. Nilai pemuliaan positif berada diatas rata-rata kelompok, sedangkan nilai pemuliaan negatif berada dibawah rata-rata kelompok.

Berdasarkan hasil analisis statistik, nilai pemuliaan bobot lahir dan bobot sapih anak jantan babi Landrace, nilai pemuliaan positif berada diatas rata-rata kelompok sedangkan nilai pemuliaan negatif berada dibawah rata-rata kelompok. Nilai pemuliaan bobot lahir anak jantan yang diatas rata-rata sebanyak 144 ekor sedangkan untuk nilai pemuliaan bobot sapih anak jantan yang diatas rata-rata sebanyak 125 ekor dari total populasi.

Anak jantan yang memiliki nilai pemuliaan berdasarkan nilai pembobotnya yang paling tinggi didalam populasinya diharapkan dapat dijadikan tetua pada generasi berikutnya. Dikarenakan anak jantan memiliki nilai pemuliaan yang tinggi diatas rata-rata mempunyai potensi yang baik untuk sifat tertentu 
untuk diturunkan ke generasi berikutnya. Menurut Kurnianto (2010) menyatakan bahwa pada program seleksi untuk memilih individu-individu ternak yang mempunyai keunggulan genetik tinggi, maka nilai pemuliaan menjadi suatu keharusan untuk diketahui. Hal ini juga sesuai dengan pernyataan Hardjosubroto (1994) yang menyatakan bahwa apabila seekor ternak (biasanya seekor pejantan) telah diketahui besar nilai pemuliaannya, hal ini berarti bahwa bila pejantan tersebut dikawinkan dengan induk-induk secara acak pada populasi normal maka rerata performans keturunannya kelak akan menunjukkan keunggulan sebesar setengah dari nilai pemuliaan pejantan tersebut terhadap performans populasinya.

Nilai pemuliaan bobot lahir anak betina babi Landrace dari hasil penelitian bernilai positif berada di atas rata-rata kelompok sebanyak 104 ekor sedangkan nilai pemuliaan bobot sapih anak betina yang di atas rata-rata sebanyak 105 ekor dari total populasi.

Anak betina yang memiliki nilai pemuliaan diatas rata-rata populasinya diharapkan dapat dijadikan induk untuk generasi selanjutnya. Pemilihan ternak berdasarkan nilai pemuliaan dapat dilihat dari besarnya nilai pembobotnya. Ternak yang mempunyai nilai pemuliaan lebih besar dari yang lainnya akan lebih baik jika dijadikan tetua bila dibandingkan dengan ternak yang memiliki nilai pemuliaan rendah. Kurnianto (2010) juga menyatakan bahwa besarnya pembobot tergantung pada sumber informasi yang digunakan untuk menduga nilai pemuliaan.

\section{KESIMPULAN}

Nilai koefisien keragaman sifat pertumbuhan pada babi Landrace memiliki keragaman yang tinggi. Nilai heritabilitas pada sifat bobot lahir tergolong sedang dan nilai heritabilitas pada sifat bobot sapih yang diperoleh dari hasil penelitian tergolong tinggi. Nilai korelasi yang rendah sampai sedang menunujukkan hubungan antar sifat belum cukup efektif terhadap percobaan seleksi. Individu dengan nilai pemuliaan diatas rata-rata kelompok dapat dijadikan ternak seleksi. 


\section{DAFTAR PUSTAKA}

Bourdon, R. M. 1997. Understanding Animal Breeding. Prentice Hall, Inc, New Jersey.

Brahmana, S.S., A.N. Barus., Irawati dan B.D. Sinuraya. 1976. Survey Breeding Performans Babi di Kecamatan Medan Labuhan. Fakultas Pertanian Universitas Sumatera Utara, Medan (Laporan Penelitian).

Cole, D.J.A dan G.R. Foxrcroft. 1982. Control of Pig Reproduction. Butterworth Scientific, London.

Dalton, D.C. 1984. An Introduction to Practical Animal Breeding. $2^{\text {nd }}$ Edition. Granada Publishing Limited. London

Davendra, C. And G.B.Mcleroy. 1982. Goat and Sheep Production in the Tropics. Longman Group Limited, Harlow, Esesex, UK

Hakim,L. 1999. Pemuliaan Ternak: Upaya Untuk Meningkatkan Performans Produksi. Pidato Pengukuhan Jabatan Guru Besar Ilmu Pemuliaan Ternak. Universitas Brawijaya. Malang.

Hardjosubroto, W.1994. Aplikasi Pemuliaan Ternak di Lapangan. Grasindo Jakarta

Kurnianto, E. 2009. Pemuliaan Ternak. Cetakan Pertama. Graha Ilmu. Yogyakarta

Kurnianto, E. 2010. Ilmu Pemuliaan Ternak. Lembaga Pengembangan dan Penjaminan Mutu Pendidikan. Universitas Diponegoro. Semarang.

Lasley, 1978. Genetics of Livestock Improvement, Third Edition Printice-Hall of India Private Limited, New Delhi.

Munir,R. 2013. Variansi dan Konvariansi. Teknik Elektro dan Informatika. ITB. Bandung.

Noor, R. R. 1996. Genetika Ternak. Cetakan Pertama Penebar Swadaya, Jakarta.

Pane, I. 1993. Pemuliabiakan Ternak Sapi. Gramedia Pustaka Utama. Jakarta.

Prihandini, P,W.,L.Hakim dan V.M.A. Nurgiartiningsih. 2011. Seleksi Pejantan Berdasarkan Nilai Pemuliaan Pada Sapi Peranakan Ongole di Loka Penelitian Sapi Potong Grati-Pasuruan. Jurnal Ternak Tropika Vol 12 No.1 hal 97-107.

Sihombing, D.T.H. 1997. Ilmu Ternak Babi. Cetakan pertama. Gadjah Mada University Press. Yogyakarta. 
Toelihere, M. 1981. Fisiologi Reproduksi pada Ternak. Angkasa, Bandung

Warwick, E. J., J. M. Astuti dan W. Hardjosubroto. 1995. Pemuliaan Ternak. Cetakan kelima. Gadjah Mada University Press, Yogyakarta.

Widodo,W. dan L.Hakim.,1981. Pemuliaan Ternak. Lembaga Penerbitan Universitas Brawijaya, Malang. 
Jurnal Peternakan Integratif Vol. 4 No.3 Agustus 2016 : 276-290 